\title{
Variation in the chemical parameters of oil extracted from arils of Blighia sapida (ackee) with the degree of fruit ripeness
}

\author{
A.J. Adepoju ${ }^{1}$, M. Abdul-Hammed ${ }^{2}$, A.O. Esan ${ }^{3}$ and M.O. Bello, \\ ${ }^{1}$ Organic and Natural Product Unit, Department of Pure and Applied Chemistry, Ladoke Akintola University of Technology, \\ Ogbomoso, Nigeria \\ ${ }^{2}$ Physical Chemistry/ Food Biophysics Unit, Department of Pure and Applied Chemistry, Ladoke Akintola University of \\ Technology, Ogbomoso, Nigeria \\ ${ }^{3}$ Industrial and Food Chemistry Unit, Department of Pure and Applied Chemistry, Ladoke Akintola University of \\ Technology, Ogbomoso, Nigeria \\ * Corresponding author E-mail: mobello427@yahoo.com
}

\begin{abstract}
The chemical properties of oil from arils of both ripe and unripe ackee (Blighia sapida) were evaluated with a view to investigating the variations in their domestic and industrial applications. The chemical analyses of ripe and unripe aril oils respectively in different locations showed the percentage yield of oil from $54.91 \pm 2.75$ to $78.25 \pm 3.91 ; 37.78 \pm 1.51$ to $54.61 \pm 2.18$, iodine values of $90.0 \pm 2.70$ to $94.5 \pm 2.84 ; 119.71 \pm 5.99$ to $131.71 \pm 6.39 \mathrm{mg} / \mathrm{g}$ oil, saponification values of $190.68 \pm 5.72$ to $201.73 \pm 6.05 ; 176.17 \pm 7.05$ to $198.15 \pm 7.9 \mathrm{mg} \mathrm{KOH} / \mathrm{g}$. Both ripe and unripe ackee arils have peroxide value less than $10 \mathrm{mEq} / \mathrm{kg}$ and acid value less than $4.0 \mathrm{mgKOH} / \mathrm{g}$. The variations between ripe and unripe ackee arils oil may prove useful in their application as cooking oils and industrial raw materials.
\end{abstract}

Keywords: Ackee arils, Chemical properties, Industrial applications, Rancidity, Ripeness

\section{Introduction}

Ackee (Blighia sapida), also known as vegetable brains (cooked fruit), is a perennial herbaceous plant introduced to Jamaica in the $16^{\text {th }}$ century mainly as a food for residents and belongs to the family of sapindaceae. Ackee. It was named scientifically to recognize Captain William Bligh, who introduced it to England in 1793[1]. The tree is originated from the Western and Central tropical Africa [2, 3]. It is planted in some countries such as Cote d'ivoire, Jamaica, Haiti and Nigeria. The ackee tree is a tropical evergreen tree that can grow as tall as 40 feet. Its leaves are broad and pinnate; its approximately $10 \mathrm{~cm}$ wide, $100 \mathrm{~g}$ Fruit may be colored anywhere from straw to bright red and splits open while still on the tree to reveal 3 glassy black seeds surrounded by a thick, oily, yellow aril. The fruit is rich in essential fatty acids, vitamin A, zinc, and protein [4]. The fruit of the tree, splits to escape a freshly cream coloured pulp (aril) attached to a shiny black oblong seed [5]. The aril is eaten fresh, raw, made into sauce, or fried in oil [6]. Ackee is widely consumed in Jamaica as part of the national dish. It is also popular among Jamaicans in the United States, United Kingdom and Canada. The main setback to its application is the toxicity which manifests as diarrhea, hypoglycemia, nausea and vomiting commonly known as Jamaican vomiting sickness or toxic hypoglycemic syndrome [7]. Documented in 1904, ackee poisoning was associated with the Jamaican vomiting sickness as first noted in 1875. A report [8] found a water-soluble toxic material in the seed and pods of the ackee fruit and two toxic compounds, namely hypoglycin A and hypoglycin B were later isolated in their crystalline form [9]. These compounds were so called because of their hypoglycemic activity. The toxicity of the hypoglycin A and B present in the unripe was shown to decrease by 13 and 7 folds respectively on ripening [7] and self-opened ackee fruits have been found to be quite safe for consumption. The present study therefore investigated the chemical properties of the oil of both unripe and "selfopened" ripe ackee (Blighia Sapida) arils in order to suggest their varied application in domestic and industrial usage. 


\section{Materials and Methods}

\subsection{Sampling}

Samples of Ackee fruits were collected from four different trees of different geographical locations in Oyo State, Nigeria during the peak fruiting season of January to March. Both the ripped and unripe of the edible were considered to make up eight samples. The first tree $\left(\left(\mathrm{T}_{1}\right)\right.$ is from Ahoyaya area in Ogbomoso South Local Government Area, the second $\left(\mathrm{T}_{2}\right)$ from General area in Ogbomoso North Local Government Area, the third tree $\left(\mathrm{T}_{3}\right)$ is from Iresaadu Village in Surulere Local Government Area while the fourth tree $\left(\mathrm{T}_{4}\right)$ is from Iluju Village in Orire Local Government Area.

\subsection{Sample labeling and preparation}

Each collected sample of both ripped and unripe edible parts of Blighia sapida were identified easily and labeled immediately. Mode of labeling was described using $\mathrm{T}$ to denote the tree from which the samples were collected, E for Edible part of the fruit as well as $\mathrm{R}$ and $\mathrm{U}$ to denote ripe and unripe edible part of the fruits respectively. For each of the trees under investigation, the arils were freed from the fruits, cleaned and dried in a cabinet oven at about $70^{\circ} \mathrm{C}$ for 3 days. The samples were then milled into powder using a KW 10 food blender.

\subsection{Moisture content determination}

About 3-5 g of each sample was weighed into a previously weighed foil. The foil containing the sample taken was then transferred into the oven set at $100^{\circ} \mathrm{C}$ to dry to a constant weight for 24 hours overnight. At the end of the 24 hours, the foil plus sample was removed from the oven and transferred into the desiccators to cool for 10 minutes and weighed. The moisture content was then calculated as reported earlier [10].

\subsection{Crude fat or ether extracts determination}

Extraction was done in batches of approximately $2 \mathrm{~g}$ of each sample with $250 \mathrm{ml}$ of petroleum ether in a soxhlet extractor. The percentage fat/oil was then determined [10].

\subsection{Acid value}

Diethyl ether and ethanol; $25 \mathrm{ml}$ each, were first mixed in a conical flask with the addition of $1 \mathrm{ml}$ phenolphthalein. The mixture was then neutralized with $0.1 \mathrm{M}$ sodium hydroxide and heated on the water bath. $2 \mathrm{~g}$ of the fat was then added into the hot neutralized mixture. The mixture was titrated with $0.1 \mathrm{M}$ potassium hydroxide until a pink colour that persisted for 15 seconds was observed. The acid value was calculated [10].

\subsection{Saponification value}

The extracted oil $(2 \mathrm{~g})$ was weighed into a conical flask and exactly $25 \mathrm{ml}$ of $0.5 \mathrm{M}$ ethanolic potassium hydroxide was added. The mixture was heated on the reflux condenser for $1 \mathrm{hr}$ with constant shaking, $1 \mathrm{ml}$ of $2 \%$ phenolphthalein indicator was then added and the hot solution was titrated against $0.5 \mathrm{M}$ hydrochloric acid. The average titre value was determined from which the saponification value was obtained as earlier reported [10].

\subsection{Unsaponifiable matter}

The titrated liquids for saponification value for each of the sample were used for the determination of unsaponifiable matter. The saponified sample solution was transferred into a separating funnel and 50ml water was used to wash the flask. The solution was then warmed. The warmed solution was extracted by adding three $50 \mathrm{ml}$ portions of diethyl ether in the separating funnel. The ether extracts (upper layer) was poured into another separator. The combined ether extracts was then washed with three $20 \mathrm{ml}$ portions of water until the wash water is no longer alkaline to phenolphthalein. The ether extract (golden yellow) was transferred into a weighed beaker and the water was then evaporated off. The dark brown residue was dried to a constant weight in the oven. The unsaponifiable matters were then calculated as previously described [10]. 


\subsection{Peroxide values}

Each sample (3g) was weighed into a $250 \mathrm{ml}$ stoppered conical flask. $10 \mathrm{ml}$ of chloroform was added to dissolve the oil and $15 \mathrm{ml}$ glacial acetic acid was also added. Then $1 \mathrm{ml}$ of freshly saturated potassium iodide solution was added and allowed to stand for 5 minutes in a dark place. $75 \mathrm{ml}$ distilled water was added to the solution and mixed. The mixture was then slowly titrated with $0.01 \mathrm{M} \mathrm{Na}_{2} \mathrm{SO}_{3}$ with vigorous shaking until the reddish colour changes to yellow. At this point $0.5 \mathrm{ml}$ of starch solution was added and the titration continued until blue- black colour disappears. The blank was also prepared following the same procedure but without the sample. The peroxide values were then calculated [10].

\subsection{Iodine number}

The extracted oil $(0.2 \mathrm{~g})$ was weighed into separate stoppered conical flask and $10 \mathrm{ml}$ chloroform added to dissolve the oil. Hanus iodine solution $(30 \mathrm{ml})$ was then added from a burette kept under the fume cupboard. The stopper was inserted and the content was mixed thoroughly without any of the solution being touched by the stopper or the neck of the conical flask and the conical flask was set aside for 30 minutes to complete the halogenation. The stopper was removed; $20 \mathrm{ml}$ of $15 \%$ potassium iodide and $100 \mathrm{ml}$ distilled water were added. The stopper was inserted and the content was mixed by shaking. The solution was then titrated immediately with $0.0877 \mathrm{M}$ standard sodium thiosulphate solution. The solution was added rapidly with stirring until most of the iodine had been titrated as shown by the solution becoming pale yellow. This point was recorded and $2 \mathrm{ml}$ starch indicator was added again and the titration continued until the blue - black disappears and the point was also recorded. Then the blank was also determined. The iodine numbers were then calculated [10].

\subsection{Statistical analysis}

All data are represented as means \pm SD for five independent determinations. Statistical analyses were performed using the Student's $t$-test on a software package, GraphPad Quick Calcs Software (from Graph Pad Software Inc. USA).

\section{Results and discussion}

Tables 1 to 4 showed the physicochemical parameters of the arils of the ackee trees from Ahoyaya area in Ogbomoso South Local Government Area $\left(\mathrm{T}_{1}\right)$, General area in Ogbomoso North Local Government Area $\left(\mathrm{T}_{2}\right)$, Iresaadu Village in Surulere Local Government Area $\left(\mathrm{T}_{3}\right)$ and Iluju Village in Oriire Local Government Area $\left(\mathrm{T}_{4}\right)$, all in Nigeria] respectively. The percentage moisture contents range from 3.33 to $5.84 \%$ for ripe arils and 4.90 to $6.16 \%$ for unripe arils. The percentage moisture contents obtained were in agreement with $6.84 \pm 1.13 \%$ moisture for sundried ackee aril from Cote d'ivoire [11]. The differences in the mean moisture content of ripe and unripe arils differ significantly $(\mathrm{P}<0.01)$ in all the trees except $\mathrm{T}_{2}(\mathrm{P}<0.05)$ with higher values recorded in the unripe edible arils.

Table 1: Chemical properties of oil from ripe and unripe Ackee aril of trees from Ahoyaya area in Ogbomoso South Local Government Area, Nigeria $\left(\mathrm{T}_{1}\right)$

\begin{tabular}{|c|c|c|c|c|c|c|c|}
\hline & $\begin{array}{l}\% \\
\text { moisture } \\
\text { content }\end{array}$ & $\%$ crude fat & Iodine value & $\begin{array}{c}\text { Saponification } \\
\text { value } \\
\text { (mg KOH/g) }\end{array}$ & $\begin{array}{c}\text { Peroxide } \\
\text { value } \\
(\mathrm{mEq} / \mathrm{kg})\end{array}$ & $\begin{array}{c}\text { Acid } \\
\text { value } \\
(\mathrm{mg} \\
\mathrm{KOH} / \mathrm{g})\end{array}$ & $\begin{array}{c}\text { Unsaponifiable } \\
\text { matter } \\
(\mathrm{g} / \mathrm{kg})\end{array}$ \\
\hline $\mathrm{T}_{1} \mathrm{ER}$ & $5.50 \pm 0.28$ & $64.18 \pm 3.21$ & $90.0 \pm 2.70$ & $196.01 \pm 5.88$ & $9.83 \pm 0.39$ & $3.37 \pm 0.17$ & $10 \pm 1$ \\
\hline $\mathrm{T}_{1} \mathrm{EU}$ & $6.15 \pm 0.25$ & $54.13 \pm 2.17$ & $119.71 \pm 5.99$ & $198.15 \pm 7.93$ & $9.00 \pm 0.27$ & $3.96 \pm 0.12$ & $11 \pm 1$ \\
\hline $\begin{array}{l}\text { a Mean } \\
\text { differences }\end{array}$ & -0.65 & 10.05 & -29.71 & -2.14 & 0.83 & 3.2 & -1 \\
\hline $\begin{array}{l}\text { P values } \\
\text { for mean } \\
\text { differences }\end{array}$ & $0.0047^{\mathrm{c}}$ & $0.0004^{\mathrm{c}}$ & $0.0001^{\mathrm{c}}$ & $0.6409^{b}$ & $0.0045^{\mathrm{c}}$ & $0.1085^{b}$ & $0.1525^{b}$ \\
\hline
\end{tabular}

${ }^{a}$ This indicates the mean values of parameters for ripe seed minus the means values of unripe ones.

Negative values indicate higher mean values for unripe seeds. ER = edible ripe arils

${ }^{\mathrm{b}}$ Mean difference is not significant

$\mathrm{EU}=$ edible unripe arils

${ }^{\mathrm{c}}$ Mean difference is significant at $\mathrm{P}<0.05$ 
Table 2: Chemical properties of oil from ripe and unripe Ackee aril of trees from General area in Ogbomoso North Local Government Area, Nigeria $\left(\mathrm{T}_{2}\right)$

\begin{tabular}{|c|c|c|c|c|c|c|c|}
\hline & $\begin{array}{c}\% \\
\text { moisture } \\
\text { content }\end{array}$ & $\%$ crude fat & Iodine value & $\begin{array}{c}\text { Saponification } \\
\text { value } \\
\text { (mg KOH/g) }\end{array}$ & $\begin{array}{l}\text { Peroxide } \\
\text { value } \\
(\mathrm{mEq} / \mathrm{kg})\end{array}$ & $\begin{array}{c}\text { Acid } \\
\text { value } \\
(\mathrm{mg} \\
\mathrm{KOH} / \mathrm{g})\end{array}$ & $\begin{array}{l}\text { Unsaponifiable } \\
\text { matter } \\
(\mathrm{g} / \mathrm{kg})\end{array}$ \\
\hline $\mathrm{T}_{2} \mathrm{ER}$ & $5.84 \pm 0.29$ & $55.45 \pm 2.77$ & $92.39 \pm 2.77$ & $201.73 \pm 6.05$ & $9.67 \pm 0.39$ & $3.9 \pm 0.20$ & $10 \pm 1$ \\
\hline $\mathrm{T}_{2} \mathrm{EU}$ & $6.16 \pm 0.25$ & $37.78 \pm 1.51$ & $125.86 \pm 6.29$ & $177.83 \pm 7.11$ & $9.00 \pm 0.27$ & $3.73 \pm 0.11$ & $15 \pm 3$ \\
\hline $\begin{array}{l}\text { Mean } \\
\text { differences }\end{array}$ & -0.32 & 17.67 & -33.47 & 23.90 & 0.67 & 0.20 & -5 \\
\hline $\begin{array}{l}\text { P values } \\
\text { for mean } \\
\text { differences }\end{array}$ & $0.0986^{b}$ & $0.0001^{\mathrm{c}}$ & $0.0001^{\mathrm{c}}$ & $0.0004^{\mathrm{c}}$ & $0.0134^{\mathrm{c}}$ & $0.0858^{b}$ & $0.0077^{\mathrm{c}}$ \\
\hline
\end{tabular}

Table 3: Chemical properties of oil from ripe and unripe Ackee aril of trees from Iresaadu Village in Surulere Local Government Area, Nigeria ( $\mathrm{T}_{3}$ )

\begin{tabular}{|c|c|c|c|c|c|c|c|}
\hline & $\begin{array}{c}\% \\
\text { moisture } \\
\text { content }\end{array}$ & $\%$ crude fat & Iodine value & $\begin{array}{c}\text { Saponification } \\
\text { value } \\
\text { (mg KOH/g) }\end{array}$ & $\begin{array}{l}\text { Peroxide } \\
\text { value } \\
(\mathrm{mEq} / \mathrm{kg})\end{array}$ & $\begin{array}{c}\text { Acid } \\
\text { value } \\
(\mathrm{mg} \\
\mathrm{KOH} / \mathrm{g})\end{array}$ & $\begin{array}{c}\text { Unsaponifiable } \\
\text { matter } \\
(\mathrm{g} / \mathrm{kg})\end{array}$ \\
\hline $\mathrm{T}_{3} \mathrm{ER}$ & $4.63 \pm .23$ & $54.91 \pm 2.75$ & $94.12 \pm 2.82$ & $203.12 \pm 6.09$ & $9.00 \pm 0.36$ & $3.38 \pm 0.17$ & $10 \pm 1$ \\
\hline $\mathrm{T}_{3} \mathrm{EU}$ & $5.36 \pm 0.21$ & $37.87 \pm 1.51$ & $131.71 \pm 6.59$ & $176.17 \pm 7.05$ & $8.10 \pm 0.24$ & $3.65 \pm 0.11$ & $15 \pm 4$ \\
\hline $\begin{array}{l}\text { a Mean } \\
\text { differences }\end{array}$ & -0.73 & 17.04 & -37.59 & 26.95 & 0.90 & -0.27 & -5 \\
\hline $\begin{array}{l}\mathrm{P} \text { values for } \\
\text { mean } \\
\text { differences }\end{array}$ & $0.0008^{c}$ & $0.0001^{\mathrm{c}}$ & $0.0001^{\mathrm{c}}$ & $0.0002^{c}$ & $0.0016^{c}$ & $0.0176^{c}$ & $0.0266^{\mathrm{c}}$ \\
\hline
\end{tabular}

a, b, c Same as in Table 1

Table 4: Chemical properties of oil from ripe and unripe Ackee aril of trees from Iluju Village in Oriire Local Government Area, Nigeria ( $\mathrm{T}_{4}$ ),

\begin{tabular}{|c|c|c|c|c|c|c|c|}
\hline & $\begin{array}{c}\% \\
\text { moisture } \\
\text { content }\end{array}$ & $\%$ crude fat & Iodine value & $\begin{array}{c}\text { Saponification } \\
\text { value } \\
\text { (mg KOH/g) }\end{array}$ & $\begin{array}{l}\text { Peroxide } \\
\text { value } \\
(\mathrm{mEq} / \mathrm{kg})\end{array}$ & $\begin{array}{c}\text { Acid } \\
\text { value } \\
(\mathrm{mg} \\
\mathrm{KOH} / \mathrm{g})\end{array}$ & $\begin{array}{l}\text { Unsaponifiable } \\
\text { matter } \\
(\mathrm{g} / \mathrm{kg})\end{array}$ \\
\hline $\mathrm{T}_{4} \mathrm{ER}$ & $3.33 \pm 0.17$ & $78.25 \pm 3.91$ & $94.5 \pm 2.84$ & $190.68 \pm 5.72$ & $9.00 \pm 0.36$ & $3.45 \pm 0.17$ & $10 \pm 1$ \\
\hline $\mathrm{T}_{4} \mathrm{EU}$ & $4.90 \pm 0.20$ & $54.61 \pm 2.18$ & $120.29 \pm 6.01$ & $182.39 \pm 7.30$ & $9.00 \pm 0.27$ & $3.31 \pm 0.10$ & $10 \pm 1$ \\
\hline $\begin{array}{l}\text { a Mean } \\
\text { differences }\end{array}$ & -1.57 & 23.64 & -25.79 & 8.29 & 0.00 & 0.14 & 0.00 \\
\hline $\begin{array}{l}\mathrm{P} \text { values for } \\
\text { mean } \\
\text { differences }\end{array}$ & $0.0001^{\mathrm{c}}$ & $0.0001^{\mathrm{c}}$ & $0.0001^{\mathrm{c}}$ & $0.0807^{b}$ & $1.0000^{b}$ & $0.1511^{b}$ & $1.0000^{b}$ \\
\hline
\end{tabular}

a, b, c Same as in Table 1

The differences also exist among the ackee trees and this may be as result of the soil conditions obtained at different geographical location of the trees. This percentage moisture content obtained is consistent with the report that the lower the moisture content, the higher the shelf life [11]. Thus the low moisture content is an indication that these oils will have high shelf life when properly packaged against external conditions.

The crude fat contents of the ripe arils ranged between 54.91 and $78.25 \%$ while that of the unripe are in the range of 37.78 to $54.61 \%$. The mean crude fat content of the ripe arils are extremely and significantly different $(\mathrm{P}<0.01)$ from that obtained with unripe edible part of the fruits. Higher crude fat content was observed with the ripe fruits. A negative correlation was observed between the moisture and crude fat contents of the arils of all the ackee trees irrespective of geographical location. The high fat content reported in this work are higher than those reported for ackee collected from 
another geographical condition [5] and also higher than the oil content of Arachis hypogaea (groundnuts, 45\%) and Moringa oleifera (moringa,41.58 \%) [12, 13]. The arils contained higher level of oil and could be a good source of fixed oil that could complement the conventional oils that are fast getting out of the reach of common people and if properly harnessed could force down the prices of these conventional oils.

The iodine values of oil of an unripe arils part from the four trees are greater than oils obtained from ripe arils with the highest values of 131.71 and 94.12 obtained for the unripe and ripe arils of tree $\mathrm{T}_{3}$ located at Surulere Local Government Area. The values obtained fall within the range of 80 - 140 reported earlier reported[14] The mean iodine values of the ripe arils are extremely and significantly different $(\mathrm{P}<0.01)$ from that obtained with unripe edible part of the fruits. Iodine values for the range above indicate higher degree of unsaturation in the extracted oil of unripe fruits. The high values so obtained correlate negatively with the low moisture contents recorded for the edible parts of the fruits. Blighia sapida arils iodine value is comparable to iodine value of groundnut oil (80-106), cotton seed (99-119), maize (103-128), seasame (104-120) and sunflower seed (120-143) [14]. Blighia sapida arils can only be classified amongst the semidrying oils [14]. Iodine value is a measure of the degree of unsaturation in oil and could be used to quantify the amount of double bonds present in the oil which reflects the susceptibility of oil to oxidation and approximately the extent of contamination in any specific oil.

In all locations, the edible ripe oils had iodine values, ranged between $90.0 \pm 2.70$ to $94.5 \pm 2.84$. Oils with Iodine value less than 100, have been classified as non-drying oils, these oils could find application as lubricant, as oils with low iodine values would not deteriorate to any appreciable extent due to oxidation and polymerization. [15]

However, the edible unripe aril oils had iodine values above 100 and in the range of $119.71 \pm 5.99$ to $131.71 \pm 6.59$. These oils are semi drying oils and might be suitable for the manufacture of paint and varnishes. For edibility purpose, oil with higher level of unsaturation is desirable, because they might not lead to heart related diseases. Thus the edible unripe aril oils might be suitable for edible purpose.

Saponification values of the ackee oil as given in the tables ranged between 176.17 and $198 \mathrm{mgKOH} / \mathrm{g}$ as well as 190.68 to $203 \mathrm{mgKOH} / \mathrm{g}$ for unripe and ripe ackee arils respectively. Saponification values for both ripe and unripe arils (edible) are very high. These values are comparable to the saponification values of palm oil (190-209), olive oil (190192), soybean oil (189-195), cotton seed oil (189-198) that are commonly used for soap making [13]. However, the mean differences between the saponification values of ripe and unripe ackee arils are insignificant $(\mathrm{P}>0.05)$ for $\mathrm{T}_{1}$ and $\mathrm{T}_{4}$ but significant $(\mathrm{P}<0.01)$ in $\mathrm{T}_{2}$ and $\mathrm{T}_{3}$. High saponification value indicates high fatty acid content [16]. Thus the ackee oils could have higher fatty acid content and might find application in soft soap manufacturing.

The peroxide values of the extracted oils ranged from 9.00 to $9.83 \mathrm{mEq} / \mathrm{kg}$ and 8.10 to $9.00 \mathrm{mEq} / \mathrm{kg}$ for ripe and unripe ackee arils respectively. The differences in the mean peroxide values of ripe and unripe arils differ significantly $(\mathrm{P}<0.01)$ in all the trees except in $\mathrm{T}_{4}(\mathrm{P}<0.05)$ with higher values recorded in the ripe edible arils. The values obtained for ackee oils was lower than $10.9 \mathrm{mEq} / \mathrm{kg}$ peroxide value reported for groundnut oil [17] but compared favorably with $8.98 \mathrm{mEq} / \mathrm{kg}$ peroxide value reported for oil of guinea peanut[15]. Peroxide value is an indication of level of rancidity of oil, but if the peroxide value of any oil is very high, it does not necessarily mean that the oil has gone rancid but it is an indication that it will soon go rancid.

The acid values are used to express the quality of free fatty acid present in the oil and the determination is often used as a general indication of the condition and edibility of oil. The acid values obtained ranged from 3.31 to $3.96 \mathrm{mgKOH} / \mathrm{g}$ for unripe ackee arils and 3.37 to 3.93 ripe ackee arils. These values are lower than the minimum safe limit of 4 $\mathrm{mgKOH} / \mathrm{g}$ set by the recommendation codex standard for edible groundnut, cotton seed, maize, rapeseed and sesame seed oils [18]. The acid values obtained show that the oils are still fresh and has a low deteriorating rate and could be suitable for cooking [19]. Unsaponifiable matter is used to test for the oil purity. The values of unsaponifiable matters ranged from 10 to $15 \mathrm{~g} / \mathrm{kg}$. The values of unsaponifiable matter indicate the unsaponified portion of the oil. That is, the material present in oils and fats which after saponification of oils or fats by caustic alkali and extraction by a suitable organic solvent remain non-volatile on drying.

\section{Conclusion}

This study showed that ripe ackee aril has higher yield of oil than unripe aril. The chemical properties of both oils are comparable to that of some conventional oils and thus could complement these oils in both domestic and industrial applications.

\section{Acknowledgements}

The authors hereby acknowledge the financial assistance of the Faculty of Pure and Applied Sciences of Ladoke Akintola University of Technology, Ogbomoso, Nigeria to Adepoju, A.J. and Esan, A.O. 


\section{References}

[1] R. J Lancashire, "The Jamaican natural fruit” 2004 . http://www.chem.uwimona.edu.jm/chrl.html on 12/10/ 2012.

[2] K. R Hill, "The Vomiting Sickness of Jamaica”, West Indian Medical Journal, 1: (1952), 243

[3] R C Bressler, K Brendel, "Hypoglycin and hypoglycin like Compounds" Pharmacological Reviews, 21,2, (1969), 105-130.

[4] S. Sharma, M.M. Yacavone , X. Cao , P.M. Samuda , J. Cade, K. Cruickshank "Nutritional composition of commonly consumed composite dishes for Afro-Caribbeans (mainly Jamaicans) in the United Kingdom" International Journal of Food Science and Nutrition 60,7, (2009), $140-150$.

[5] E. T. Akintayo, E. A. Adebayo, L.A. Arogunde "Assessment of dietary exposure to the natural toxin hypoglicin in ackee (Blighia sapida)". Jamaican Food Research International, 37, (2002), 833-838.

[6] M. Arbonnier “ Arbres, arbustes et lianes des Zones seches d' Afrique de I'Ouest” Edition 2, CIRAD- MNHN: (2002), 173-179.

[7] S. Mitchell, A. W. Seymour, M. Ahmad “Ackee, Jamaica's top fruit” Jamaican Journal of Science and Technology, 31, (2008), 84-89.

[8] E. O. Jordan, W. Burrow "The vomiting sickness of Jamaica, B.W.I. and its relation to ackee poisoning". American Journal of Hygiene, 25 (1937), 520-545

[9] C. H. Hassel, K. Reyle "Hypoglycin A, B: biologically active polypeptides from Blighia sapida" Nature, 173, (1954), $356-357$.

[10] Association of Official Analytical Chemists (AOAC). Official Methods of Analysis 15th Edition .Washington, D. C. (1990), 955-972

[11] H. Quattara, B. Niamke , T. Dally, C. S. Kati "Nutritional composition studies of sundried Blighia sapida aril" Journal of Applied Biosciences, 32, (2010), 1989-1994.

[12] FAO "Legumineuses, noix et graines oleagineuses." La nutrition dan less pays en development,2000

[13] B. A. Anhwange, V. O. Ajibola, S. J. Oniye "Chemical studies of seeds of Moringa oleifera (Lam) and Detarium microcarpum (Guill and Sperr)" Journal of Biological Sciences 4, 6, (2004), 711-715.

[14] D. Pearson “ Chemical analysis of food" Medical division of Longman group Ltd., London, 8th edition,(1981), 515-536

[15] M.O. Bello, N.O. Olawore, O.O. Fapojuwo, O.S. Falade, S.R.A. Adewusi "Nutritional Quality of seed and Physicochemical properties of Oil of Guinea peanut (Bombax glabra Pasq.)" Advances in Food and Energy Security. 1 : (2011), 1-7

[16] S.A. Amusa, E. N. Anderson-foster, J. Nilza "Physico-chemical properties of Blighia sapida (ackee) oil extract and its potential application as emulsion base". African Journal of pharmacy and Pharmacology, $63: 2012$, 200-210.

[17] O.S. Falade, S. A. Adekunle, M. A Aderogba, O. S. Atanda, C. Harwood, S. R. A. Adewusi " Physicochemical properties, Total phenol and Tocopherol of some Acacia Seed oils" J. Sci. Food Agric., 88, (2008) ,263-268

[18] O. J. Abayeh, E. A. Aina , C. O. Okounghae, "Oil Content and oil quality characteristics of some Nigeria oil seeds" Science Forum. Journal of Pure and Applied Science, 1,1, (1998), 17- 23

[19] O. D. Ekpa, U. J. Ekpa, "Comparison of the characteristic parameters and deterioration properties of oil from the Tenera and Dura variety of the oil palm" Nigerian Journal of Chemical Research, 1, (1996), 26-33.

[20] R. Joskow, M. Belson, H. Vesper, L. Backer, C. Rubin“ Ackee fruit poisoning: An Outbreak Investigation in Haiti 2000-2001 and review of the literature" Clinical Toxicology, 44, 3, (2006), 267-273.

[21] J. Moya "Ackee (Blighia sapida) poisoning in the Northern Province, Haiti” Epidemiology Bulletin, 22,2,(2001) , 8-9.

[22] H. A. S. Sherratt, S. S. Al-Bassam "Glycine in ackee poisoning” Lancet, 309, (1976) , 604. 